\title{
Factors Affecting Online Donation Intention in Donation-Based Crowdfunding
}

\author{
Irantha Hendrika Kenang ${ }^{1 *}$, Gladys Gosal ${ }^{2}$ \\ ${ }^{1,2}$ Faculty of Management and Business, Ciputra University Surabaya \\ CitraLand CBD Boulevard, Made, Kec. Sambikerep, Kota SBY, Jawa Timur 60219, Indonesia \\ 1irantha.hendrika@ciputra.ac.id; ${ }^{2}$ gladys.gosal@ciputra.ac.id
}

Received: $28^{\text {th }}$ February 2021/ Revised: $12^{\text {th }}$ April 2021/ Accepted: $12^{\text {th }}$ April 2021

\begin{abstract}
How to Cite: Kenang, I. H. \& Gosal, G. (2021). Factors affecting online donation intention in donation-based crowdfunding. The Winners, 22(2), 97-104. https://doi.org/10.21512/tw.v22i2.7101
\end{abstract}

\begin{abstract}
The research aimed to determine factors affecting online donation intention of Generation Y, particularly in donation-based crowdfunding in Indonesia. Applying a quantitative method, the research used a combination of Theory of Planned Behavior (Attitude, Subjective Norms, Perceived Behavioral Control), Social Presence Theory, and S-O-R Theory (Website Quality, Transaction Convenience, Perceived Credibility). The research used purposive sampling with total of 118 respondents. The result of the analysis suggests that millennials' intention to donate is significantly affected by the perceived credibility of the crowdfunding platform. This is mainly due to online transaction hence the donors are concerned about whether their donation is going to be distributed properly. Subsequently, the perceived credibility of crowdfunding platform is significantly affected by social presence, website quality, and transaction convenience, which support previous research related to Social Presence Theory and S-O-R Theory. Meanwhile, attitude, subjective norms, and perceived behavioral control have no significant impact on intention to donate, which may be due to several issues such as trust and security issues considering the donation is conducted through online. The crowdfunding platforms and fundraisers in Indonesia are expected to have guidelines about important aspects that may affect individual's intention to donate in crowdfunding platform.
\end{abstract}

Keywords: online donations, donation intention, crowdfunding

\section{INTRODUCTION}

The development of the digital world has encouraged many industrial sectors to digitize their business due to the increasing number of people using internet technology to support their activities. Evidence from Indonesian Internet Service Providers Association (APJII) shows that the number of internet users in Indonesia per 2020 reaches 196,71 million from 266,91 population $(73,7 \%)$, which increased by $8,9 \%$ from the previous year (APJII, 2020). Based on this phenomenon, it can be said that digital trends have become the lifestyle of Indonesians.

One of the activities that is currently following the digital trend is online donation. Now, many nonprofit organizations are starting to leave conventional ways and switch to using digital platforms to raise donations. This is also supported by the rapid growth of financial technology (fintech) companies that have created digital wallets and make it easier for people to donate through their phones. This phenomenon led to the emergence of online fundraising platforms, commonly known as donation-based crowdfunding, where the nominal of donation is decreased but the amount is increased (Putri, 2020). The increase in digital donation through crowdfunding platform in Indonesia has more than doubled since 2017 ("Indonesia negara paling", 2018).

Crowdfunding is a general term used to describe various forms of fundraising where a group of people raises money to achieve a specific goal, which is usually done via the internet (Ahlers et al., 2015). According to Vismara (2019), crowdfunding can be divided into four types: 1) reward-based crowdfunding, 2) lendingbased crowdfunding, 3) equity-based crowdfunding, and 4) donation-based crowdfunding. In reward-based crowdfunding, people who contribute to fundraising will be rewarded with products or services. Lendingbased crowdfunding means that the borrowers will receive fixed interest on the funds they lend. In equitybased crowdfunding, the entrepreneur opens an offer to sell a portion of his company's equity on the internet. Meanwhile, in donation-based crowdfunding, individuals or organizations raise funds for a purpose 
without giving anything to the donor.

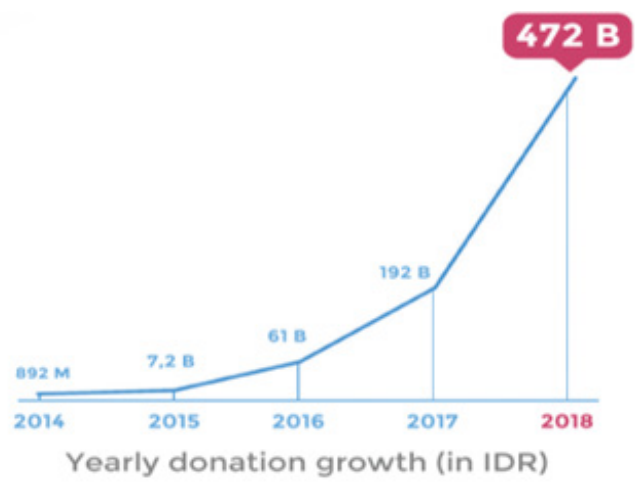

Figure 1 Donation Growth in Indonesia Source: ("Indonesia negara paling", 2018)

The reasons individuals choose to contribute to crowdfunding platforms vary. Several researchers have analyzed the reasons for contributing ranging from a desire for reward, financial gain, curiosity about potential crowdfunding, to a desire to be part of the community (Choy \& Schlagwein, 2016; Gerber \& Hui, 2013). Donation-based crowdfunding, which is the focus of the research, is a type of crowdfunding whose activities are different from other types of crowdfunding. The party donating money does not expect financial rewards or benefits, but is based on altruistic factors which prioritize the needs of others rather than oneself. Donation-based crowdfunding does not assume a real reward for contributions. Nevertheless, contributors obtain the sense of satisfaction since they have committed to a cause they care about (Bukhari et al., 2019). Unlike traditional charity projects, donation-based crowdfunding adds an information technology element to the donation process, so the attributes that influence the intention to donate should be considered more than traditional charity projects. Given that the success of a crowdfunding project depends entirely on the involvement of supporters, it is important to analyze the attributes that influence the intention to donate through donation-based crowdfunding.

Based on the data presented in Figure 1, it is clear that donation-based crowdfunding in Indonesia is growing rapidly. However, not all donation projects carried out has always succeeded in meeting the targets within the predetermined time. This failure can be caused by many factors which then lead to the closure of several online donation platforms (Pratama, 2017). Therefore, to find out what factors can influence the success of online fundraising, a research needs to be done to provide benefits for both the platform provider and the fundraiser. The research discusses several factors that influence individual's intention to donate based on several existing theories starting from the Theory of Planned Behavior (TPB), Social Presence Theory, and S-O-R Theory (Stimulus, Organism, Response).
Theory of Planned Behavior (TPB) aims to understand and predict human behavior (Sura, Ahn \& Lee, 2017). The concept of TPB explains that the intention behavior is influenced by psychological emotions that come from consumer evaluations, perceptions of social pressure and expectations to behave, and perceptions of ease or difficulty in behaving (Ajzen, 1991). These three factors form attitudes, subjective norms, and perceived behavioral control, which ultimately affect the behavioral intention. Many studies have proven that these three factors have positive influence on behavioral intention (Tenkasi \& Zhang, 2018; Paul, Modi \& Patel, 2016; Webb et al., 2000) TPB has also been used in several studies related to individual behavior in donating (Chen et al., 2019; Sura et al., 2017; Knowles et al., 2012)

Attitude is considered to be the most important factor affecting behavior intention (Kotchen \& Reiling, 2000). The more positive the attitude towards the behavior, the stronger the intention to behave (Sura et al., 2017). Subjective norms are based on the influence of other people, such as friends, family, and colleagues that encourage social pressure from a behavior (Chen et al., 2019). Consumers who have positive subjective norms for a behavior are more likely to be willing to realize that behavior (Han \& Kim, 2010). Behavioral control depends on the extent to which individuals feel that factors such as resources, time, and colleague cooperation can inhibit or facilitate behavioral intentions (Tenkasi \& Zhang, 2018). Many literatures show that perceived behavioral control is positively correlated with intention (Chen \& Tung, 2014: Teng, $\mathrm{Wu}, \& \mathrm{Liu}, 2015)$. From the discussion, the hypotheses can be formulated:

$\mathrm{H}_{1}$ : Attitude has a positive effect on the intention to donate in donation-based crowdfunding.

$\mathrm{H}_{2}$ : Subjective Norms have a positive effect on the intention to donate in donation-based crowdfunding.

$\mathrm{H}_{3}$ : Perceived Behavioral Control has a positive effect on the intention to donate in donation-based crowdfunding.

The most striking difference between traditional charity projects and charity projects using internet media is the social experience that is felt when donating (Chen et al., 2019). Social context, which relates to direct interactions with other parties, is important in influencing trust (Gefen \& Straub, 2004). Social Presence Theory describes how this social context affects the use of communication media. High social presence is usually found in face-to-face communication while low social presence is often found in e-mails and paper-based letters (Gefen \& Straub, 2004). However, although websites tend not to involve real interactions with other people, it does not mean that social presence cannot be implemented on websites. Choi (2016) states that social presence can be 
felt in internet communication media by using social cues such as text, images, and sounds simultaneously. An example of social guidance applied by the Kitabisa. com website is by storytelling, which highlights the details of people related to the donation project and the situations around them to create empathy of potential donors.

Social presence has been shown to have a strong impact on building trust in the virtual world (Srivastava \& Chandra, 2018). Research has proven that social presence has an important role in influencing a person's trust in the credibility of a communication medium (Choi, 2016; Lu et al., 2016). This is due to its ability to create personal relationships with other users and interpersonal relationships through the website, which ultimately increases trust (Choi et al., 2011). Furthermore, Chen et al. (2019) find that social presence positively influences donor trust in donationbased crowdfunding. Therefore, the hypothesis can be stated:

$\mathrm{H}_{4}$ : Social presence has a positive effect on perceived credibility in donation-based crowdfunding.

The S-O-R theory is put forward by Mehrabian \& Russell (1973), with the explanation that environmental stimuli (S) lead to emotional reactions $(\mathrm{O})$ that trigger behavioral responses $(\mathrm{R})$. Since this model can explain a person's decisionmaking process (Richard et al., 2009) along with the development of technology, many researchers are interested in exploring the S-O-R framework in online communication media (Kim \& Lennon, 2013). The model proposed based on this theory is how technological characteristics (stimulus) drive people's perceptions of project's credibility (organism), which in turn influences their intention to donate (response) in donation-based crowdfunding.

The S-O-R theory is put forward by Mehrabian \& Russell (1973), with the explanation that environmental stimuli (S) lead to emotional reactions $(\mathrm{O})$ that trigger behavioral responses $(\mathrm{R})$. Since this model can explain a person's decisionmaking process (Richard et al., 2009) along with the development of technology, many researchers are interested in exploring the S-O-R framework in online communication media (Kim \& Lennon, 2013). The model proposed based on this theory is how technological characteristics (stimulus) drive people's perceptions of project's credibility (organism), which in turn influences their intention to donate (response) in donation-based crowdfunding.

$\mathrm{H}_{5}$ : Website quality has a positive effect on the perceived credibility of donation-based crowdfunding. $\mathrm{H}_{6}$ : Transaction convenience has a positive effect on perceived credibility in donation-based crowdfunding.

Online behavior is facilitated by the perceived credibility of both the platform and the transaction provider (Cheung et al., 2009). In the context of donation-based crowdfunding, individuals donate without expecting anything in return, hence it is natural for them to worry about whether their donation will be misused for other purposes. In other words, individuals will try to evaluate whether the fundraiser can be trusted upon donating through crowdfunding platform (Liu et al., 2018). In addition, transactions that occur in donation-based crowdfunding are transactions between strangers who do not know each other, which can lead to the potential of information asymmetry and even fraud for all parties involved in the transaction (Chen et al., 2019). Therefore, perceived credibility plays a crucial role in crowdfunding projects as potential donors rely on it to decide whether to donate their money to the respective project. The following hypothesis can be formulated:

$\mathrm{H}_{7}$ : Perceived credibility has a positive effect on the intention to donate in donation-based crowdfunding.

Finally, the overall research framework is presented in Figure 2.

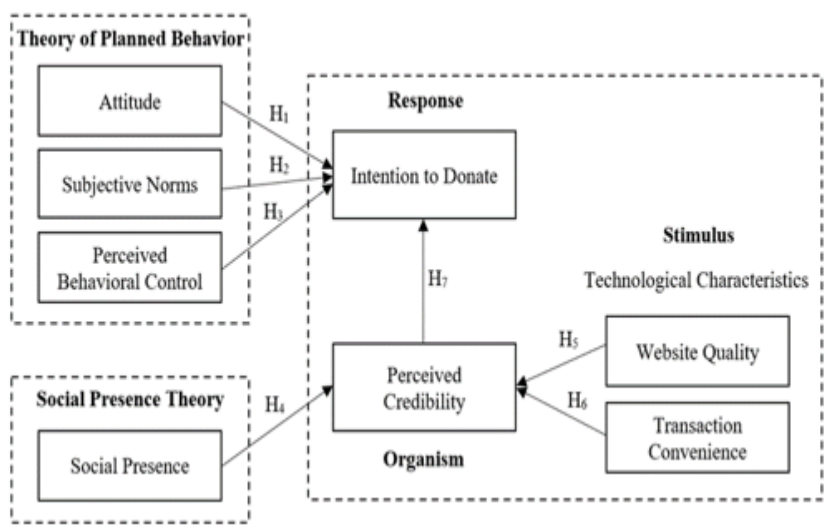

Figure 2 Research Framework

\section{METHODS}

The research applies a quantitative approach that aims to test predetermined hypotheses based on pre-existing theories and concepts as well as previous research (Cooper \& Schindler, 2014). The research uses non-probability sampling where samples are selected using purposive sampling with several criteria which are limited to a specific type of group that provides the desired information, or fits the criteria determined by the researcher (Sekaran \& Bougie, 2016)

The first criteria is that the respondents have been looking for information about donation-based crowdfunding platform, specifically Kitabisa.com, but have never made digital donations. Kitabisa. com is chosen since it has succeeded in becoming the most popular online donation platform due to the convenience it offers in the process of raising funds, security, and donations that are distributed right on target. Kitabisa.com has successfully raised more than 500 billion rupiahs since 2014 and has been disbursed 
according to their respective allocations. Especially for the COVID-19 pandemic period from March to May 2020, the donations raised by this platform reached 130 billion rupiahs with millions of donors (Riana, 2020).

The second criteria is that respondents must be between the ages of 20 to 40 years old by 2020 since the research focuses on millennials (Millennial Generation or Gen Y). Despite the different opinions regarding the age range of the millennial generation from various researchers, the research refers to the Indonesia Millennial Generation Profile, which concludes that millennials are born within the year 1990 to 2000 (Kemenpppa, 2018). The recap of millennial generation by birth is shown in Figure 3 .

According to Deloitte (2019), millennials will be the majority generation in Indonesia's demographic structure until 2045. It is one of the generations that are said to always want to connect and adopt a digital lifestyle. Besides that, the millennials are the ones who care about social missions. This is proved by a report which states that the increase in digital donations in Indonesia has more than doubled since 2017 and 60\% of the donations came from millennials ("Indonesia negara paling", 2018). Some of the previous statements and facts are the important aspects of the research due to the close relation to the variables studied.

Furthermore, the number of samples are taken with the consideration that the number is at least 10 times the number of variables studied, thus the required minimum sample is $10 \times 8=80$ respondents. Data is collected by distributing questionnaires to respondents via Google Form using a 5-point Likert scale. The research uses the structural equation modeling (SEM)

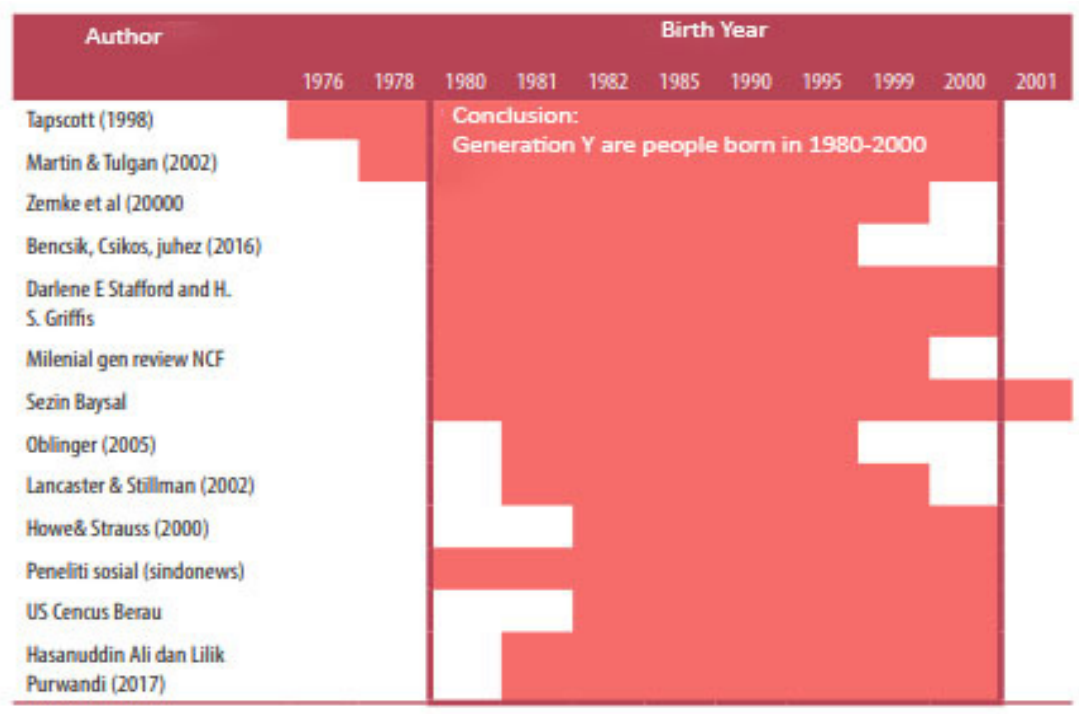

Figure 3 Recap of Millennial Generation by Birth Year Based on Various Researchers Source: Kemenpppa (2018)

Table 1 Outer Loading, AVE \& Composite Reliability

\begin{tabular}{lcccc}
\hline \multicolumn{1}{c}{ Variable } & Indicator & Outer Loading & AVE & Composite Reliability \\
\hline Attitude & ATT1 & 0,824 & 0,667 & 0,889 \\
& ATT2 & 0,783 & & \\
ATT3 & 0,867 & & 0,856 \\
Subjective Norms & ATT4 & 0,790 & & 0,925 \\
Perceived Behavioral Control & SN1 & 0,851 & 0,666 & \\
& SN2 & 0,876 & & \\
& SN4 & 0,713 & 0,754 & 0,927 \\
Social Presence & PBC1 & 0,886 & & \\
& PBC2 & 0,793 & & \\
& PBC3 & 0,904 & 0,719 & \\
& PBC4 & 0,887 & & \\
\end{tabular}


Table 1 Outer Loading, AVE \& Composite Reliability (Continued)

\begin{tabular}{|c|c|c|c|c|}
\hline Variabele & Indicator & Outer Loading & AVE & Composite Reliability \\
\hline & SP5 & 0,795 & & \\
\hline \multirow[t]{9}{*}{ Website Quality } & WQNAV1 & 0,739 & 0,566 & 0,921 \\
\hline & WQNAV2 & 0,810 & & \\
\hline & WQNAV3 & 0,735 & & \\
\hline & WQSEC1 & 0,691 & & \\
\hline & WQSEC2 & 0,712 & & \\
\hline & WQSEC3 & 0,717 & & \\
\hline & WQVA1 & 0,771 & & \\
\hline & WQVA2 & 0,790 & & \\
\hline & WQVA3 & 0,797 & & \\
\hline \multirow[t]{4}{*}{ Transaction Convenience } & $\mathrm{TC} 1$ & 0,897 & 0,814 & 0,946 \\
\hline & $\mathrm{TC} 2$ & 0,924 & & \\
\hline & TC3 & 0,898 & & \\
\hline & TC4 & 0,890 & & \\
\hline \multirow[t]{6}{*}{ Perceived Credibility } & CRED1 & 0,873 & 0,756 & 0,949 \\
\hline & CRED2 & 0,901 & & \\
\hline & CRED3 & 0,874 & & \\
\hline & CRED4 & 0,889 & & \\
\hline & CRED5 & 0,862 & & \\
\hline & CRED6 & 0,815 & & \\
\hline \multirow[t]{2}{*}{ Intention to Donate } & INTD1 & 0,972 & 0,943 & 0,971 \\
\hline & INTD2 & 0,970 & & \\
\hline
\end{tabular}

Source: Data Processed, 2020

Table 2 Fornell-Larcker Criterion

\begin{tabular}{lcccccccc}
\hline \multicolumn{1}{c}{ Variable } & ATT & INTD & PBC & CRED & SP & SN & TC & WQ \\
\hline ATT & 0,817 & & & & & & & \\
INTD & 0,485 & 0,971 & & & & & & \\
PBC & 0,543 & 0,428 & 0,868 & & & & & \\
CRED & 0,432 & 0,625 & 0,336 & 0,869 & & & & \\
SP & 0,591 & 0,519 & 0,604 & 0,572 & 0,848 & & & \\
SN & 0,622 & 0,358 & 0,583 & 0,234 & 0,555 & 0,816 & & \\
TC & 0,439 & 0,546 & 0,436 & 0,708 & 0,499 & 0,269 & 0,902 & \\
WQ & 0,570 & 0,641 & 0,528 & 0,729 & 0,611 & 0,472 & 0,785 & 0,753 \\
\hline
\end{tabular}

Source: Data Processed, 2020

method with the Partial Least Square-SEM (PLSSEM) approach for hypothesis testing.

\section{RESULTS AND DISCUSSIONS}

In the pilot testing conducted initially on 30 samples, the SN3 indicator is found to be invalid and thus eliminated. Table 1 and Table 2 show the results of validity and reliability tests after the indicators mentioned are eliminated.

Overall, the total number of respondents is 118 , where this number have met the minimum sample in the research. The male respondents are $40 \%$ and the other $60 \%$ are female. The largest age group is 20 30 years old $(85 \%)$ and the rest is $31-40$ years old $(15 \%)$. Viewed from the level of education, most of the respondents have a bachelor's degree $(81 \%)$, while the other $19 \%$ have graduated from high school. In terms of monthly expenditures, $55 \%$ of respondents has expenditures of more than 3 million rupiahs, the other $19 \%$ has between 2-3 million rupiahs and the rest of them has under 2 million rupiahs per month. Furthermore, $37 \%$ of respondents states that they donate almost once a month in a year, another $20 \%$ donates every 2-4 months in a year and the rest donates 
every 6 months in a year.

Table 3 shows the correlation between variables through the R-squared test where it can be concluded that the social presence, website quality and transaction convenience affect perceived credibility by $59,2 \%$, and the other $40,8 \%$ are influenced by other variables. Meanwhile, the intention to donate is influenced by attitude, subjective norms, perceived behavioral control, and perceived credibility by $45 \%$ and the rest is influenced by other variables.

Table 3 R-Squared Test Result

\begin{tabular}{lc}
\hline \multicolumn{1}{c}{ Variable } & R-Squared \\
\hline Perceived Credibility & $59,2 \%$ \\
Intention to Donate & $45 \%$ \\
\hline
\end{tabular}

Source: Data Processed, 2020

Furthermore, Table 4 shows the results of the t-test carried out to see the significance level of the initial research hypothesis. The hypothesis is accepted and the variable is declared to have a significant effect if it has a t-statistic value higher than 1,98.

Table 4 shows that there are several hypotheses that are accepted and there are also hypotheses that are rejected. In the context of Theory of Planned Behavior, it can be seen that all three hypotheses are rejected. Attitude, subjective norms and perceived behavioral control do not have a significant effect on the intention to donate in donation-based crowdfunding. This is different from the results of previous studies which did not specifically lead to donations in crowdfunding platform (Tenkasi \& Zhang, 2018; Paul et al., 2016; Webb et al., 2000). Viewed from the results of the descriptive analysis, the indicator on the highest attitude variable is the attitude of donating which is considered good by the respondent. Nevertheless, it does not immediately make the respondent confident enough to donate through crowdfunding. This is supported by the fact that perceived behavioral control also has no significant effect on the intention to donate to donation-based crowdfunding. The results of the descriptive analysis show that the respondents have full control over where they will donate. In fact, the respondents remain hesitant to donate through crowdfunding. This statement is supported by data from the GoPay Digital Donation Outlook (Kopernik, 2020) which explains that donors are in doubt whether the donations reach the right party if made online. In addition, issues related to security when donating are a consideration for donors not to donate digitally. Furthermore, subjective norms did not have a significant effect on the intention to donate in donationbased crowdfunding, which supports previous research conducted by Chen et al. (2019). The relationship between subjective norms and behavioral intention has been criticized by several previous researchers. Ajzen (1991) argues that subjective norms have the weakest correlation to behavioral intention compared to attitudes and perceptions of behavior control due to the fact that intention is highly influenced by personal factors.

Meanwhile, the results indicate that social presence has a significant influence on the perceived credibility of users in donation-based crowdfunding. This is in line with previous research which confirms the significant influence of social presence on donors' trust in donation-based crowdfunding (Chen et al., 2019; Choi et al., 2011). High social presence can increase user trust since it serves as a cue that increasing social presentation will also increase the donor's perception of the credibility of a project (Gefen \& Straub, 2004).

Furthermore, the research results show that there is a significant effect of technological characteristics on the perception of credibility in donation-based crowdfunding, thus supporting previous research conducted by Liu et al. (2018). This indicates that when individuals have a positive affection for the quality of the website and the ease of the transaction process in donating, the perception of the credibility of the crowdfunding platform increases. This statement is supported by data from the GoPay Digital Donation Outlook (Kopernik, 2020) which concludes that one of the main reasons for donors to donate through crowdfunding platforms is the convenience factor supported by technology.

Finally, the results confirm the significant influence of perceived credibility on the intention to donate through donation-based crowdfunding. This is

Table 4 Hypothesis Testing

\begin{tabular}{lccl}
\hline \multicolumn{1}{c}{ Hypothesis } & Original Sample & t-test & \multicolumn{1}{c}{ Result } \\
\hline H1: Attitude $\rightarrow$ Intention to Donate & 0,156 & 1,625 & Not Significant \\
H2: Subjective norms $\rightarrow$ Intention to Donate & 0,063 & 0,708 & Not Significant \\
H3: Perceived Behavioral Control $\rightarrow$ Intention to Donate & 0,139 & 1,383 & Not Significant \\
H4: Social Presence $\rightarrow$ Perceived Credibility & 0,191 & 2,180 & Significant \\
H5: Website Quality $\rightarrow$ Perceived Credibility & 0,341 & 3,027 & Significant \\
H6: Transaction Convenience $\rightarrow$ Perceived Credibility & 0,345 & 2,634 & Significant \\
H7: Perceived Credibility $\rightarrow$ Intention to Donate & 0,495 & 5,983 & Significant \\
\hline
\end{tabular}

Source: Data Processed, 2020 
in line with previous research by Liu et al. (2018) and Lu et al. (2016) who state that the perceived credibility of a charity crowdfunding project has a strong role in determining an individual's intention to donate. Since donations made through crowdfunding are done online, donors are more likely to question whether the money is distributed to those in need. If they believe that the money will not be misused, they will donate without hesitation. In other words, perceived credibility is one of the main factors influencing intention to donate through crowdfunding platforms.

\section{CONCLUSIONS}

The research is expected to enrich the Theory of Planned Behavior (TPB), Social Presence and S-O-R Theory applications, especially in donation-based crowdfunding platform. The results shows that attitude, subjective norms, and perceived behavioral control do not have a significant effect on the intention to donate in donation-based crowdfunding which may be due to several issues such as level of trust and security issues considering the donations is conducted through virtual network. Furthermore, the research results prove that there is a significant influence of social presence, website quality, and transaction convenience on the perceived credibility of Kitabisa.com as a donationbased crowdfunding platform, which in turn has a significant impact on the intention to donate.

The research results are expected to be an input for the digital donation platform to build credibility by sharing information in the form of positive storytelling so that it can strengthen social presence which has an impact on increasing trust. Crowdfunding platforms or fundraisers also need to pay attention to the quality of websites or digital media used to communicate with donors. Visual and audiovisual displays need to be considered, so they look attractive to donors as well as being designed to be a user-friendly platform. Furthermore, related to the convenience of transactions, crowdfunding platform providers can offer various payment options to make it easier for donors to channel their donations either through digital wallets, bank transfers, or collaboration with merchants that donors can easily find. In addition, the option of the auto-debit feature can also be made to help donors who may want to make donations regularly without having to transfer manually.

It is necessary to note that the research is only limited to a specific crowdfunding platform, which is Kitabisa.com. Therefore, further research is recommended not only on crowdfunding platform but also on online donations using other channels such as social media or digital wallet. In addition, other variables can be added relating to the factors affecting intention to donate, such as characteristics of the donation project or moderating variables such as income or generation other than millennials.

\section{REFERENCES}

Ahlers, G. K. C., Cumming, D., Günther, C., \& Schweizer, D. (2015). Signaling in equity crowdfunding. Entrepreneurship Theory and Practice, 39(4), 955980. https://doi.org/10.1111\%2Fetap. 12157

Ajzen, I. (1991). The theory of planned behavior. Organizational Behavior and Human Decision Processes, 50(2), 121-179. https://doi. org/10.1016/0749-5978(91)90020-T

APJII. (2020). Laporan Survei Internet APJII 2019 - 2020. Asosiasi Penyelenggara Jasa Internet Indonesia, 2020, 1-146. https://apjii.or.id/survei

Bukhari, F. A. S., Usman, S. M., Usman, M., \& Hussain, K. (2019). The effects of creator credibility and backer endorsement in donation crowdfunding campaigns success. Baltic Journal of Management, 15(2), 215235. http://dx.doi.org/10.1108/BJM-02-2019-0077

Chen, M.-F. \& Tung, P.-J. (2014). Developing an extended theory of planned behavior model to predict consumers' intention to visit green hotels. International Journal of Hospitality Management, 36, 221-230. https://psycnet.apa.org/doi/10.1016/j. ijhm.2013.09.006

Chen, Y., Dai, R., Yao, J., \& Li, Y. (2019). Donate time or money? The determinants of donation intention in online crowdfunding. Sustainability, 11(16). https:// doi.org/10.3390/su11164269

Cheung, M., Luo, C., Sia, C., \& Chen, H. (2009). Credibility of electronic word-of-mouth: Informational and normative determinants of on-line consumer recommendations. International Journal of Electronic Commerce, 13(4), 9-38. https://doi. org/10.2753/JEC1086-4415130402

Choi, J., Lee, H. J., \& Kim, Y. C. (2011). The influence of social presence on customer intention to reuse online recommender systems: The roles of personalization and product type. International Journal of Electronic Commerce, 16(1), 129-154. https://doi.org/10.2753/ JEC1086-4415160105

Choi, S. (2016). The flipside of ubiquitous connectivity enabled by smartphone-based social networking service: Social presence and privacy concern. Computers in Human Behavior, 65, 325-333. http:// dx.doi.org/10.1016/j.chb.2016.08.039

Choy, K. \& Schlagwein, D. (2016). Crowdsourcing for a better world: On the relation between IT affordances and donor motivations in charitable crowdfunding. Information Technology \& People, 29(1), 221-247. https://doi.org/10.1108/ITP-09-2014-0215

Cooper, D. R. \& Schindler, P. S. (2014). Business Research Methods $\left(12^{\text {th }}\right.$ Ed.). McGraw-Hill Higher Education.

Deloitte. (2019). Millennials in Industry 4.0: A Gift or a Threat to Indonesian Human Resources? (1 ${ }^{\text {st }}$ Ed.). Deloitte Indonesia. https://www2.deloitte.com/ content/dam/Deloitte/id/Documents/about-deloitte/ id-about-dip-edition-1-chapter-2-en-sep2019.pdf

Gefen, D. \& Straub, D. W. (2004). Consumer trust in B2C e-commerce and the importance of social presence: Experiments in e-products and e-services. Omega, 32(6), 407-424. https://doi.org/10.1016/j. 
omega.2004.01.006

Gerber, E. M. \& Hui, J. (2013). Crowdfunding: Motivations and deterrents for participation. ACM Transactions on Computer-Human Interaction, 20(6). https://doi. org/10.1145/2530540

Gregg, D. G. \& Walczak, S. (2010). The relationship between website quality, trust and price premiums at online auctions. Electronic Commerce Research, 10(1), 1-25. https://doi.org/10.1007/s10660-0109044-2

Han, H. \& Kim, Y. (2010). An investigation of green hotel customers' decision formation: Developing an extended model of the theory of planned behavior. International Journal of Hospitality Management, 29(4), 659-668. http://dx.doi.org/10.1016/j. ijhm.2010.01.001

Indonesia negara paling dermawan di dunia. (2018, December 31). Kitabisa.com. https://blog.kitabisa. com/kitabisa-online-giving-report-2018-indonesia/

Kemenpppa. (2018). Profil Generasi Milenial Indonesia. Kementerian Pemberdayaan Perempuan dan Perlindungan Anak. https://kemenpppa.go.id/lib/ uploads/list/9acde-buku-profil-generasi-milenia.pdf.

Kim, J. \& Lennon, S. J. (2013). Effects of reputation and website quality on online consumers' emotion, perceived risk and purchase intention. Journal of Research in Interactive Marketing, 7(1), 33-56. https://doi.org/10.1108/17505931311316734

Kim, S. \& Stoel, L. (2004). Dimensional hierarchy of retail website quality. Information \& Management, 41(5), 619-633. https://doi.org/10.1016/j.im.2003.07.002

Knowles, S. R., Hyde, M. K., \& White, K. M. (2012). Predictors of young people's charitable intentions to donate money: An extended theory of planned behavior perspective. Journal of Applied Social Psychology, 42(9), 2096-2110. https://doi. org/10.1111/j.1559-1816.2012.00932.x

Kopernik. (2020). Gopay Digital Donation Outlook $2020 . \quad$ https://v1.kopernik.info/documents/ document/1608187207118_8549.pdf.

Kotchen, M. J. \& Reiling, S. D. (2000). Environmental attitudes, motivations, and contingent valuation of nonuse values: A case study involving endangered species. Ecological Economics, 32(1), 93-107. https://doi.org/10.1016/S0921-8009(99)00069-5

Liu, L., Suh, A., \& Wagner, C. (2018). Empathy or perceived credibility? An empirical study on individual donation behavior in charitable crowdfunding. Internet Research, 28(3), 623-651. http://10.0.4.84/ IntR-06-2017-0240.

Lu, B., Fan, W., \& Zhou, M. (2016). Social presence, trust, and social commerce purchase intention: An empirical research. Computers in Human Behavior, 56, 225-237. http://dx.doi.org/10.1016/j. chb.2015.11.057

Mehrabian, A. \& Russell, J. A. (1973). A measure of arousal seeking tendency. Environment and Behavior, 5(3), 315-333. https://psycnet.apa.org/ doi/10.1177/001391657300500303

Paul, J., Modi, A., \& Patel, J. (2016). Predicting green product consumption using theory of planned behavior and reasoned action. Journal of Retailing and Consumer Services, 29, 123-134. https://econpapers.repec. org/scripts/redir.pf?u=https $\% 3 \mathrm{~A} \% 2 \mathrm{~F} \% 2 \mathrm{Fdoi}$. org\%2F 10.1016\%252Fj.jretconser.2015.11.00 06;h=repec:eee:joreco:v:29:y:2016:i:c:p:123-134

Pratama, A. H. (2017, February 2). Gagal sukseskan banyak proyek, situs crowdfunding wujudkan hentikan layanan. Techinasia. https://id.techinasia.com/situscrowdfunding-wujudkan-tutup-layanan-pada-31maret-2017

Putri, V. M. (2020, May 20). Dompet digital dan donasi online munculkan tren micro giving. detikinet. https://inet.detik.com/cyberlife/d-5022821/dompetdigital-dan-donasi-online-munculkan-tren-microgiving.

Riana, F. (2020, May 15). Total donasi di Kitabisa.com mencapai Rp 130 miliar saat pandemi. Tempo. co. https://nasional.tempo.co/read/1342578/totaldonasi-di-kitabisa-com-mencapai-rp-130-miliarsaat-pandemi

Richard, D. M., Dawes, M. A., Mathias, C. W., Acheson, A., Hill-Kapturczak, N., \& Dougherty, D. M. (2009). L-tryptophan: basic metabolic functions, behavioral research and therapeutic indications. International Journal of Tryptophan Research, 23(2), 45-60. https://doi.org/10.4137/ijtr.s2129

Sekaran, U. \& Bougie, R. (2016). Research Methods for Business: A Skill Building Approach. John Wiley \& Sons.

Srivastava, S. C. \& Chandra, S. (2018). Social presence in virtual world collaboration: An uncertainty reduction perspective using a mixed methods approach. MIS Quarterly, 42(3), 779-804. https://doi.org/10.25300/ MISQ/2018/11914

Sura, S., Ahn, J., \& Lee, O. (2017). Factors influencing intention to donate via social network site (SNS): From Asian's perspective. Telematics and Informatics, 34(1), 164-176. https://doi. org/10.1016/j.tele.2016.04.007

Teng, Y.-M., Wu, K.-S., \& Liu, H.-H. (2015). Integrating altruism and the theory of planned behavior to predict patronage intention of a green hotel. Journal of Hospitality \& Tourism Research, 39(3), 299-315. https://doi.org/10.1177\%2F1096348012471383

Tenkasi, R. R. V. \& Zhang, L. (2018). A test of the theory of planned behavior: Influencing behavioral change to go "Green". Research in Organizational Change and Development, 26, 127-165. https://doi.org/10.1108/ S0897-301620180000026004

Vismara, S. (2019). Sustainability in equity crowdfunding. Technological Forecasting and Social Change, 141, 98-106. https://doi.org/10.1016/j. techfore.2018.07.014

Webb, D. J., Green, C. L., \& Brashear, T. G. (2000). Development and validation of scales to measure attitudes influencing monetary donations to charitable organizations. Journal of the Academy of Marketing Science, 28(2), 299-309. https://psycnet. apa.org/doi/10.1177/0092070300282010 